\title{
FAKTOR RESIKO YANG MEMPENGARUHI TERJADINYA KETUBAN PECAH DINI: SURVEY STUDY
}

\author{
The Risk Faktors That Influenced Of Premature Rupture Of Membrane: A Survey \\ Study
}

\author{
Sabi'ah Khairi ${ }^{1}$, Nur Tawajjuh ${ }^{2}$, Nyoman Tribuana Tungga Dewi ${ }^{3}$, Meti Karmayanti ${ }^{4}$ \\ ${ }^{1}$ Program Studi Pendidikan Ners STIKES YARSI Mataram, Mataram, NTB, Indonesia \\ ${ }^{2-4}$ Unit Berslin RSUD Provinsi Nusa Tenggara Barat, Mataram, NTB, Indonesia \\ Korespondensi: sabiahkhairi@gmail.com
}

\begin{abstract}
ABSTRAK.
Ketuban pecah dini (KPD) merupakan penyebab tidak langsung kematian ibu. Ada beberapa faktor resiko yang menyebabkan terjadinya KPD diantaranya adalah Riwayat anemia dalam kehamilan, Riwayat infeksi saluran kemih, status social ekonomi rendah, Riwayat KPD sebelumnya dan lain-lain. Tujuan dari penelitian ini adalah untuk mengetahui faktor resiko terjadinya KPD baik dari faktor social demografi maupun faktor kondisi klinis di Ruang Bersalin RSUD Provinsi NTB. Metode Penelitian ini merupakan penelitian kuantitatif dengan desain deskriptif. Pengambilan data dilakukan secara retrospektif dengan melihat medical record dari responden yang mengalami KPD pada tahun 2019 sejumlah 175 responden. Analisis data menggunakan analisis univariat yakni melihat presentase faktor resiko. Hasil penelitian menunjukkan status multigravida tingkat pendidikan menengah dan status tidak bekerja merupakan faktor sosio demografi terbanyak masing-masing sebesar 53\%, 63,8\% dan 86\%. Dari faktor kondisi klinis riwayat infeksi merupakan faktor resiko yang paling menonjol pada pasien KPD yakni sebanyak 119 responden (68\%), sementara itu, Riwayat anemia dalam kehamilan menjadi faktor kondisi klinis ke dua terbanyak sebesar $45 \%$ atau 79 responden. Temuan penelitian ini dapat dijadikan penguatan kepada ibu hamil dengan optimalisasi pelaksanaan kegiatan kelas ibu di puskesmas serta dapat lebih meningkatkan promosi kesehatan dan inovasi pembelajaran baik di desa maupun di puskesmas.
\end{abstract}

Kata Kunci: faktor resiko, KPD, sosio-demografi, kondisi klinis

\section{ABSTRACT}

Premature rupture of membrane (PROM) is an indirect causes of maternal mortality. There are risk factors that related of PROM such as anemic during pregnancy, history of infection in tractus urinary, and low social status. The purpose of this study was to described risk factors related to PROM either from social demographics factors or clinical conditions in delivery room general hospital of West Nusa Tenggara Province. This research is descriptive study with retrospective method. It used secondary data from 175 medical records of respondents who have been PROM in 2019. Univariate analysis was used in this study to data analysis. The results of this study show that multiparitas, low education levels and don't have a job are the highest factors of social demographics approximately 53\%, 63,8\% and 86\% respectively. Meanwhile, the infection history is the highest number of clinical conditions (68\%) and anemic during pregnancy is the second most common faktors related to PROM (45\%). The result of this study can be used as reinforcement for pregnant women by optimizing the implementation of maternal class in public health center. Other than it can improve health promotion program and learning innovation both in the rural and health center.

Keyword: risk faktors, PROM, social demographics, clinical condition 
Sabi'ah Khairi, dkk: Faktor resiko yang mempengaruhi terjadinya ketuban pecah dini di ruang bersalin RSUD Provinsi NTB: Survey Study

\section{PENDAHULUAN}

Munculnya kesadaran akan pentingnya kesehatan wanita didasari atas meningkatnya jumlah angka kematian ibu, angka kematian bayi, wanita dan anak-anak yang hidup dibawah garis kemiskinan, bahkan meningkatnya jumlah wanita yang mengidap AIDS. Padahal indeks keberhasilan pembangunan suatu negara bergantung pada rendahnya angka kematian ibu (AKI) dan dan angka kematian bayi (AKB) (J.Reeder, Martin, \& KoniakGriffin, 2012). Berdasarkan data Kementerian Kesehatan RI (2018) angka kematian ibu di Indonesia pada tahun 2015 mencapai angka 305/100.000 kelahiran hidup. Angka ini mengalami penurunan dibanding angka kematian ibu pada tahun 2012 yaitu sebesar 359/100.000 kelahiran hidup. Selain AKI, AKB juga merupakan salah satu indikator keberhasilan pembangunan suatu bangsa. AKB mengalami penurunan dari tahun ketahun. Pada tahun 2007 AKB di Indonesia mencapai angka 34/1000 kelahiran hidup, tahun 2012 sebesar 32/1000 kelahiran hidup dan pada tahun 2017 turun menjadi 24/1000 kelahiran hidup (Kementerian Kesehatan RI, 2018).

Penyebab tingginya AKI dan AKB di Indonesia tidak terlepas dari masalah komplikasi kehamilan, persalinan maupun nifas. Tiga penyebab utama yang teridentifikasi pada tahun 2013 terdiri atas perdarahan $(30,3 \%)$, hipertensi $(27,1 \%)$, dan infeksi $(7,3 \%)$. Berdasarkan laporan Pusat Data dan Informasi Kementerian Kesehatan RI (2014), disebutkan bahwa jumlah kasus kematian ibu akibat lain-lain juga merupakan penyebab yang paling mendominasi yakni sebesar $40,8 \%$. Oleh karena itu, perhatian besar terhadap kesehatan ibu terutama berfokus pada periode perinatal yaitu pada seluruh tahap kehamilan, kelahiran maupun nifas. Hal ini yang mendasari munculnya program Making Pragnancy Safer (MPS) oleh WHO tahun 1990 dengan menempatkan safe motherhood sebagai prioritas utama dalam rencana pembangunan nasional dan internasional (Indriyani, 2013). Demikian juga upaya yang terus dilakukan oleh Kementrian Kesehatan Republik Indonesia sejak tahun 2012 telah meluncurkan program EMAS (expanding maternal and neonatal survival) yang diharapkan dapat menurunkan angka kematian ibu dan neonatal sebesar $25 \%$.

Kategori lain dari penyebab AKI adalah penyebab tidak langsung seperti penyakit jantung, paru yang menyertai selama kehamilan maupun kondisi-kondisi kegawatdaruratan yang mengancam keselamatan ibu maupun janin (Pusat Data dan Informasi Kementerian Kesehatan RI, 2014). Ketuban pecah dini (KPD) yang dikenal dengan istilah PROM (premature rupture of membrane) atau PPROM (preterem premature rupture of membrane) merupakan salah satu komplikasi kehamilan maupun persalinan yang sering terjadi pada ibu. Kondisi ini dapat mengancam keselamatan ibu maupun janin dari infeksi yang dapat ditimbulkan dengan tidak adanya barrier selaput ketuban yang melindungi janin dari lingkungan ekstra uteri.

Banyaknya kasus KPD ini terjadi disebabkan oleh beberapa faktor resiko. Menurut Koroveshi, Kuli-Lito, Korosevhi, Bylykbashi, \& Nurce (2018), kondisi klinis terkait faktor resiko dari KPD diantaranya adalah infeksi saluran kemih, status social ekonomi rendah, riwayat persalinan premature sebelumnya, IMT kurang dari normal, riwayat perokok atau sering terpapar asap rokok dan tindakan amniosintesis. American Association of Pro-Life Obstetricians \& Gynecologists (2018) menyatakan bahwa dampak yang dapat ditimbulkan akibat terjadinya PPROM adalah terjadinya chorioamnionitis atau infeksi pada selaput dan air ketuban. Kondisi ini sangat beresiko meningkatkan morbiditas maternal yakni resiko terjadi sepsis, tindakan section caesaria, histerektomi, endometritis post partum, perdarahan post partum bahkan kematian ibu.

Penelitian yang telah dilakukan oleh Huda (2013), menunjukkan bahwa survey yang dilakukan pada 125 responden terkait faktor resiko yang mempengaruhi KPD ditemukan memiliki riwayat pre-eklmasia, anemia dalam kehamilan, kehamilan gemeli, riwayat hidramnioan dan kelaianan 
Sabi'ah Khairi, dkk: Faktor resiko yang mempengaruhi terjadinya ketuban pecah dini di ruang bersalin RSUD Provinsi NTB: Survey Study

letak sungsang. Faktor resiko yang cukup banyak ini yang menyebabkan kejadian KPD merupakan komplikasi dengan angka tertinggi pada persalinan. Dilihat dari karakteristik ibu yang mengalami KPD, dari beberapa hasil penelitian menunjukkan bahwa ibu dengan multigravida dan status social ekonomi kurang memiliki resiko terjadi KPD. Hal ini dikaitkan bahwa ibu dengan paritas tinggi dikaitkan dengan kekuatan dan pertumbuhan selaput ketuban dalam menyangga konsepsi selama kehamilan. Dikatakan bahwa kehamilan terlalu sering dapat mempengaruhi embriogenesis, selaput ketuban lebih tipis sehingga lebih cepat pecah sebelum waktunya. Selain itu, ibu dengan paritas tinggi dapat menyebabkan struktur servik mengalami kerusakan pada persalinan sebelumnya sehingga dapat meningkatkan infeksi pada amnion (Rahayu \& Sari, 2017).

Di Amerika Serikat, angka kejadian ibu bersalin dengan KPD mencapai 150.000 kasus setiap tahunnya (Koroveshi et al., 2018). KPD yang terjadi pada usia kehamilan aterm terjadi sekitar $8-10 \%$, sementara itu KPD yang terjadi pada kehamilan kurang bulan sebesar $1 \%$ (Rahayu \& Sari, 2017). Di Rumah Sakit Umum Daerah Provinsi Nusa Tenggara Barat, kasus ibu bersalin dengan KPD merupakan kasus terbanyak dari 9 kasus yang dirawat diruang bersalin. Berdasarkan data pelaporan kejadian kasus komplikasi kehamilan dan persalinan diruang bersalin RSUD Provinsi NTB pada 2 tahun terakhir, terlihat kasus KPD merupakan kejadian terbanyak berturut-turut sebesar 452 kasus pada tahun 2017, dan 310 kasus pada tahun 2018.

Petugas kesehatan memiliki peranan yang cukup penting dalam melakukan penanganan kasus KPD, cepat dan tanggap dalam mengatasi kemungkinan dampak yang dapat terjadi dari kondisi KPD, serta memiliki peran dalam mencegah dan meminimalisir kejadian KPD untuk bisa menekan angka kesakitan maupun kematian yang dapat ditimbulkan oleh kompilkasi ini. Melihat kejadian KPD ini merupakan kasus terbanyak dalam 2 tahun berturut-turut yang ada di RSUD Provinsi NTB, sehingga peneliti tertarik untuk melakukan studi survey terkait faktor resiko kejadian KPD di ruang bersalin RSUD Provinsi NTB baik dari kondisi klinis yang menyertai maupun dari karakteristik sosio demografi responden. Penelitian ini merupakan penelitian pendahulu untuk nantinya menjadi data dasar sebagai evidence base practice dalam mengetahui kondisi spesifik yang akan mempengaruhi pengambilan keputusan dalam memberikan asuhan kepada pasien dengan KPD

\section{TUJUAN PENELITIAN}

Tujuan dari penelitian ini adalah untuk mengetahui faktor resiko terjadinya KPD di Ruang Bersalin RSUD Provinsi NTB

\section{METODE}

Desain

Penelitian ini merupakan penelitian kuantitatif. Desain yang digunakan adalah deskriptif, yaitu untuk mengetahui gambaran faktor resiko yang mempengaruhi kejadian KPD. Pengambilan data terhadap variabel penelitian menggunakan pendekatan retrospektif, dimana pengambilan data variabel penelitian dilakukan terhadap kejadian KPD yang sudah terjadi dalam 1 tahun terakhir dengan menggunakan data skunder.

\section{Populasi dan Sampel}

Populasi dalam penelitian ini adalah seluruh ibu bersalin yang mengalami kasus ketuban pecah dini yang terjadi dalam 1 tahun terakhir di tahun 2018. Adapun jumlah populasi kejadian KPD dalam 1 tahun terakhir berjumlah 310 kasus. Sampel yang mewakili populasi dalam penelitian ini diambil dengan menggunakan rumus perhitungan sampel menurut Slovin. Dengan menggunakan derajat penyimpangan sebesar 5\% atau sebesar 0,05 (tingkat kebenaran 95\%), maka jumlah sampel yang diambil sebesar 175 responden. 
Sabi'ah Khairi, dkk: Faktor resiko yang mempengaruhi terjadinya ketuban pecah dini di ruang bersalin RSUD Provinsi NTB: Survey Study

Tempat dan Waktu Penelitian

Penelitian ini dilaksanakan di ruang bersalin RSUD Provinsi NTB. Waktu pelaksanaan penelitian akan dilaksanakan pada bulan Maret sampai dengan April 2019.

\section{Instrumen dan Prosedur Pengukuran}

Penelitian ini tidak menggunakan instrument spesifik karena hanya melakukan pengambilan data menggunakan data rekam medis pasien. Proses pengumpulan data penelitian dilakukan melalui tahapan berikut ini:

1. Identifikasi jumlah kejadian KPD dalam 1 tahun yang ada di ruang bersalin RSUD Provinsi NTB

2. Melakukan kerjasama dengan bagian rekam medis RSUD Provinsi NTB untuk mengambil jumlah sampel sebanyak 175 kasus melalui register pasien yang telah diidentifikasi

3. Mengambil data sekunder dengan melihat faktor-faktor resiko yang terdiri dari karakteristik responden meliputi: (1) umur, (2) usia kehamilan, (3) status social ekonomi (tingkat pendidikan dan penghasilan), (4) jenis kehamilan (tunggal/gemeli) dan (5) paritas. Selain itu juga diambil data faktor resiko dari kondisi klinis yang menyertai meliputi: (1) infeksi traktus genital, (2) PEB, (3) anemia dalam kehamilan, (4) kelainan letak, (5) riwayat KPD sebelumnya dan (6) polihidramnion.

4. Melakukan pengisian data sesuai dengan faktor resiko yang telah diidentifikasi kedalam instrument yang dibuat dalam bentuk master tabel

\section{Analisa Data}

Analisa data dalam peneitian ini dilakukan dengan analisis univariat, yaitu mengelompokkan data satu persatu sesuai faktor resiko yang diteliti.

\section{HASIL PENELITIAN}

Berikut ini akan dijabarkan hasil penelitian yang diperoleh dari hasil pengumpulan data. Hasil penelitian akan disajikan dalam bentuk tabel distribusi frekuensi yakni terdiri dari hasil penelitian faktor resiko dari karakteristik sosio demografi respionden dan faktor resiko berdasarkan kondisi klinis responden dengan total sampel sebanyak 175 responden.

\section{Tabel 1}

Karakteristik Responden Berdasarkan Sosio-Demografi $(n=175)$

\begin{tabular}{lcc}
\hline \multicolumn{1}{c}{ Karakteristik } & f & $\mathbf{\%}$ \\
\hline Usia & & \\
$<20$ tahun & 8 & 4,5 \\
20-35 tahun & 134 & 76,5 \\
$>35$ tahun & 33 & 19 \\
Paritas & & \\
$\quad$ Primipara & 75 & 43 \\
Multipara & 92 & 53 \\
Grand multipara & 8 & 4 \\
Pendidikan & & \\
Tidak/belum pernah sekolah & 5 & 2,9 \\
Tidak tamat SD/MI & 0 & 0 \\
Tamat SD/MI & 34 & 19,5 \\
Tamat SLTP/SMP & 51 & 29,1 \\
Tamat SLTA/MA & 61 & 34,7 \\
Tamat D1/D2/D3 & 5 & 2,9 \\
Tamat PT & 19 & 10,9 \\
Pekerjaan & & \\
Bekerja & 23 & 13,1 \\
Tidak bekerja & 152 & 86,9 \\
\hline
\end{tabular}

Berdasarkan data yang terlihat pada tabel 1 diatas, maka terlihat bahwa usia responden penelitian sebagian besar pada usia produktif (20-35 tahun) yakni sebesar $76,5 \%$, sebagian besar dari responden memiliki paritas multigravida (53\%), tingkat pendidikan sebagian besar berada pada tingkat menengah yakni SLTP sebesar $29,1 \%$ dan SLTA sebesar 34,7\%. Sedangkan untuk status pekerjaan sebagian besar tidak bekerja $(86,9 \%)$.

Tabel 2

Karakteristik Responden Berdasarkan Kondisi Klinis ( $\mathrm{n}=175)$

\begin{tabular}{lcc}
\hline Karakteristik & f & $\mathbf{\%}$ \\
\hline Usia Kehamilan & & \\
Pre Term $(\leq 36$ minggu $)$ & 45 & 26 \\
Aterm $(37-40$ minggu $)$ & 123 & 70 \\
Post Term $(\geq 40$ minggu $)$ & 7 & 4 \\
Riwayat Infeksi & & \\
Ya (leukosit $>11.000)$ & 119 & 68 \\
Tidak & 56 & 32 \\
Riwayat KPD Sebelumnya & & \\
Ya & 2 & 1.1 \\
Tidak & 173 & 98,9 \\
\hline Riwayat Preeklampsia Berat & &
\end{tabular}


Sabi'ah Khairi, dkk: Faktor resiko yang mempengaruhi terjadinya ketuban pecah dini di ruang bersalin RSUD Provinsi NTB: Survey Study

\begin{tabular}{|c|c|c|}
\hline $\mathrm{Ya}$ & 21 & 12 \\
\hline Tidak & 154 & 88 \\
\hline Riwayat & & \\
\hline \multicolumn{3}{|l|}{ Kehamilan } \\
\hline Anemia ringan $(8-10 \mathrm{gr} / \mathrm{dl})$ & 76 & 43.4 \\
\hline Anemia sedang $(6-7,9 \mathrm{gr} / \mathrm{dl})$ & 3 & 1,7 \\
\hline Anemia berat $(<6 \mathrm{gr} / \mathrm{dl})$ & 0 & 0 \\
\hline Tidak anemia & 96 & 54,9 \\
\hline \multicolumn{3}{|l|}{ Riwayat Servik Inkompeten } \\
\hline $\mathrm{Ya}$ & 12 & 6,9 \\
\hline Tidak & 163 & 93,1 \\
\hline \multicolumn{3}{|l|}{ Kelainan Letak Janin } \\
\hline $\mathrm{Ya}$ & 24 & 13,7 \\
\hline Tidak & 151 & 86,3 \\
\hline \multicolumn{3}{|l|}{ Kehamilan Gemeli } \\
\hline $\mathrm{Ya}$ & 2 & 1.1 \\
\hline Tidak & 173 & 98,9 \\
\hline \multicolumn{3}{|l|}{ Riwayat Polihidramnion } \\
\hline $\mathrm{Ya}$ & 3 & 1,7 \\
\hline Tidak & 172 & 98,3 \\
\hline
\end{tabular}

Berdasarkan data mengenai kondisi klinis yang menyertai responden yang tersaji pada tabel 2 diatas menunjukkan bahwa riwayat infeksi merupakan faktor resiko yang paling menonjol yang ditemukan pada responden penelitian yang mengalami KPD yakni sebesar $68 \%$ yakni sebanyak 119 responden. Faktor resiko berikutnya yang terlihat cukup menonjol yang terjadi pada responden yang mengalami KPD adalah kondisi anemia selama kehamilan. Terdapat 79 responden $(45 \%)$ yang mengalami anemia dalam kehamilan yang didominasi anemia ringan sebanyak 76 (43,4\%). Sementara itu faktor resiko lain seperti riwayat KPD sebelumnya, riwayat preeclampsia, servik inkompeten, kelainan letak janin, kehamilan gemeli dan riwayat polihdramnion tidak menjadi faktor yang mendominasi responden yang mengalami anemia.

\section{PEMBAHASAN}

Hasil analisis dari table distribusi frekuensi terkait faktor resiko yang mempengaruhi terjadinya KPD terlihat bahwa terdapat 4 faktor yang dominan terjadi pada responden yang mengalami KPD. 2 dari 4 faktor tersebut adalah dari faktor sosio demografi yaitu faktor multigravida dan tingkat pendidikan, sedangkan 2 faktor lainnya adalah dari faktor kondisi klinis yaitu faktor riwayat infeksi dan kejadian anemia dalam kehamilan.

Beberapa referensi menyatakan bahwa paritas multigravida memiliki resiko terjadinya KPD. Hal ini berkaitan dengan proses persalinan yang berkali-kali terjadi terlebih pada ibu dengan paritas grandmultigravida ( $>4$ kali hamil) akan menyebabkan trauma pada dinding servik. Uterus mengalami kelemahan secara intrinsik karena adanya trauma pada persalinan sebelumnya sehingga beresiko terjadinya ketuban pecah dini (Wulandari, 2016).

Rahayu \& Sari (2017) juga menyatakan bahwa paritas tinggi meningkatkan resiko terjadinya KPD. Hal ini dikaitkan bahwa ibu dengan paritas tinggi dikaitkan dengan kekuatan dan pertumbuhan selaput ketuban dalam menyangga konsepsi selama kehamilan. Dikatakan bahwa kehamilan terlalu sering dapat mempengaruhi emriogenesis, selaput ketuban lebih tipis sehingga lebih cepat pecah sebelum waktunya. Selain itu, ibu dengan paritas tinggi dapat menyebabkan struktur servik mengalami kerusakan pada persalinan sebelumnya sehingga dapat meningkatkan infeksi pada amnion.

Faktor sosio demografi lainnya yang menonjol adalah faktor tingkat pendidikan. Dari hasil penelitian terlihat bahwa sebagian besar responden memiliki tingkat pendidikan menengah dan dasar (146 responden). Responden yang memiliki tingka pendidikan SD sebanyak 34 orang $(19,5 \%)$, SLTP sebanyak 51 orang $(29,1 \%)$ dan SLTA sebanyak 61 orang (34,7\%). Tingkat pendidikan dapat dikaitkan dengan seberapa besar pengetahuan dan pemahaman yang dimiliki seseorang terhadap kesehatan. Asrinah, Putri, Sulistyorini, Muflihah, \& Sari (2009) menyatakan bahwa tingkat pendidikan yang dimiliki seseorang akan dapat mempengaruhi pola pikir orang tersebut. Jika tingkat pendidikan seseorang tinggi maka cara berfikir seseorang akan semakin luas, meningkatkan kematangan intelektual sehingga mampu dalam mengambil keputusan yang tepat dalam bertindak dan memilih pelayanan kesehatan. Lebih lanjut 
Sabi'ah Khairi, dkk: Faktor resiko yang mempengaruhi terjadinya ketuban pecah dini di ruang bersalin RSUD Provinsi NTB: Survey Study

dikatakan bahwa wanita seharusnya memperhatikan kesehatan reproduksi khususnya memiliki pengetahuan tentang kesehatan selama kehamilan dan persalinan. Dengan level pendidikan yang tinggi dimungkinkan wanita memilki pengetahuan yang lebih tentang bagiamana dan menjaga kesehatan selama kehamilan apa saja yang harus dipersiapkan dalam proses persalinan sehingga harapannya proses kehamilan dan persalinan dapat berjalan dengan lancar (Asrinah et al., 2009)

Dari hasil penelitian terkait dengan status social demografi responden terlihat bahwa sebagian besar responden berada pada status social menengah kebawah, yakni sebagian besar memiliki pendidikan dasar menengah dan sebagian besar juga merupakan ibu rumah tangga. Hal ini sejalan dengan pendapat yang diutarakan oleh (Rahayu \& Sari, 2017) serta (Koroveshi et al., 2018) bahwa status sosial ekonomi yang rendah merupakan salah satu faktor resiko yang menyebabkan terjadinya KPD pada ibu hamil.

Hasil lainnya yang ditemukan dari penelitian ini adalah faktor resiko berdasarkan kondisi klinis yang dialami oleh responden. Dari table hasil terihat bahwa kondisi infeksi menduduki peringkat pertama dari faktor resiko terjadinya KPD yakni sebesar $68 \%$ dari total responden. Kondisi infeksi disini terlihat dari hasil pemeriksaan darah kengkap yang menunjukkan angka leukosit lebih dari 11.000. Banyak literatur yang mendukung teerkait keadaan infeksi dapat mencetus terjadinya KPD. Salah satu diantaranya adalah menurut American Association of Pro-Life Obstetricians \& Gynecologists (2018) menyatakan bahwa infeksi yang terjadi pada traktus genitalia wanita dapat mencetus terjadinya infeksi pada cairan ketuban (corioamninitis). Kondisi infeksi yang terjadi pada selaput ketuban ini sangat mempengaruhi terjadinya kerapuhan pada selaput ketuban sehingga rentan terjadi ketuban pecah dini. infeksi yang terjadi pada vagina dan saluran genital lainnya baik luar maupun dalam juga dapat menyebabkan terjadinya ketuban pecah dini. Inflamasi yang terjadi pada traktus genitalia dapat masuk menginfeksi lapisan selaput ketuban sehingga menyebabkan ketuban pecah dini (Koroveshi et al., 2018).

Jakovljević et al. (2014) menyatakan bahwa salah satu infeksi yang dapat menyebabkan terjadinya ketuban pecah dini adalah infeksi yang terjadi pada vagina. Bakteri yang menyerang area vagina yang disebut dengan bacterial vaginosis akan berdampak pada ekosistem vagina, yang akan menurunkan atau menghilangkan kadar hydrogen peroxida yang memproduksi lactobasillus pada vagina sehingga dapat membuat bakteri anaerob berkembang biak di area vagina menyebabkan infeksi. Berkembangnya kuman an aerob ini dalam jumlah yang sangat banyak akan sangat beresiko masuk kedalam uterus sehingga dapat menginfeksi selaput ketuban dan menyebabkan ketuban pecah dini (Jakovljević et al., 2014).

Faktor lain secara klinis yang juga terlihat cukup banyak terjadi pada responden yang mengalami KPD adalah kondisi anemia dalam kehamilan. Terlihat pada tabel hasil bahwa responden yang mengalami anemia adalah sebesar 45\% dengan anemia ringan yang paling dominan terjadi dari seluruh responden yang mengalami anemia. Kondisi anemia merupakan keadaan dimana kadar hemoglobin dalam darah mengalami penurunan. Hemoglobin berfungsi sebagai pengikat oksigen dalam darah yang dibutuhkan oleh sel-sel diseluruh tubuh. Jika seseorang mengalami anemia maka oksigen dalam darah akan berkurang sehingga dapat menyebabkan kelemahan fisik, sakit kepala dan tidak bertenaga. Terlebih jika ibu hamil mengalami anemia maka sangat rentan terjadi perdarahan baik dalam kehamilan maupun pada saat persalinan (Perry, Hockenberry, Lowdermilk, \& Wilson, 2010).

Kondisi anemia juga dapat mempengaruhi selaput ketuban saat kehamilan. Anemia menyebabkan gangguan degenerasi dan perfusi selaput ketuban sehingga menyebabkan kerapuhan pada selaput ketuban. Lebih lanjut dikatakan bahwa anemia pada kehamilan menyebabkan berkurangnya massa hemoglobin di dalam jaringan sehingga tidak mampu memenuhi fungsinya sebagai 
Sabi'ah Khairi, dkk: Faktor resiko yang mempengaruhi terjadinya ketuban pecah dini di ruang bersalin RSUD Provinsi NTB: Survey Study

pembawa oksigen keseluruh tubuh. Kurangnya oksigenasi terutama jaringan ketuban akibatnya menimbulkan kerapuhan pada selaput ketuban (Herawati \& Astuti, 2010).

\section{KESIMPULAN}

Implikasi

Hasil penelitian terkait faktor resiko yang mempengaruhi terjadinya ketuban pecah dini di ruang bersalin RSUD Provinsi NTB menunjukkan ada 4 faktor yang dominan terjadi pada responden yang mengalami KPD. 2 dari 4 faktor tersebut adalah dari faktor sosio demografi yaitu faktor multigravida dan tingkat pendidikan, sedangkan 2 faktor lainnya adalah dari faktor kondisi klinis yaitu faktor riwayat infeksi dan kejadian anemia dalam kehamilan. Hasil penelitian ini diharapkan dapat menjadi informasi bagi masyarakat untuk dapat mencegah terjadinya ketuban pecah dini pada wanita hamil dengan meningkatkan kebersihan diri terutama daerah kewanitaan agar tidak mudah terkena infeksi pada traktus gentialis. Selain itu ibu hamil juga perlu memahami tentang pentingnya gizi selama kehamilan untuk mencegah terjadinya anemia serta perlu memahami tentang jarak kehamilan. Peran petugas kesehatan khsusnya yang bertugas pada pelayanan tingkat pertama baik di Puskesmas maupun Polindes untuk terus memberikan edukasi kepada ibu hamil. Penguatan kepada ibu hamil dapat lebih diberikan saat pelaksanaan kegiatan kelas ibu di puskesmas serta dapat lebih meningkatkan promosi kesehatan dan inovasi pembelajaran baik di desa maupun di puskesmas

\section{Keterbatasan}

Penelitian ini memiliki beberapa keterbatasa antara lain: (1) hasil penelitian tidak dapat digeneralisir karena hanya dilakukan pada satu rumah sakit, dan (2) beberapa data sekunder dari rekam medis tidak semua menuliskan data terkait faktorfaktor resiko yang menyebabkan terjadinya KPD sesuai variable penelitian sehingga beberapa responden menjadi ekslusi.

\section{DAFTAR PUSTAKA}

American Association of Pro-Life Obstetricians \& Gynecologists. (2018). Previable Induction of Labor for Chorioamnionitis: Issues in Law \& Medicine. AAPLOG Practice Bulletin, 33(2), 247-257.

Asrinah, Putri, S. S., Sulistyorini, D., Muflihah, I. S., \& Sari, D. N. (2009). Asuhan Kebidanan Masa Kehamilan. Yogyakarta: Graha Ilmu.

Herawati, C., \& Astuti, S. (2010). FaktorFaktor yang Berhubungan dengan Anemia Gizi Pada Ibu Hamil di Puskesmas Jalaksana Kuningan Tahun 2010. Jurnal Kesehatan Kartika, 5158.

Huda, N. (2013). Faktor-Faktor yang Mempengaruhi Ketuban Pecah Dini di RS PKU Muhammadiyah Surakarta. Universitas Muhammadiyah Surakarta.

Indriyani, D. (2013). Keperawatan Maternitas Pada Area Perawatan Antenatal. Yogyakarta: Graha Ilmu.

J.Reeder, S., Martin, L. L., \& KoniakGriffin, D. (2012). Keperawatan Maternitas: Kesehatan Wanita, Bayi dan Keluarga. (Y. Afiyanti, I. N. Rachmawati, \& S. Djuwitaningsih, Eds.) (18th ed.). Jakarta: EGC.

Jakovljević, A., Bogavac, M., Nikolić, A., Milošević Tošic, M., Novakovicć, Z., \& Stajić, Z. (2014). The influence of bacterial vaginosis on gestational week of the completion of delivery and biochemical markers of inflammation in the serum. Vojnosanitetski Pregled, 71(10), 931935.

Kementerian Kesehatan RI. (2018). Profil Kesehatan Indonesia 2017. Jakarta.

Koroveshi, G., Kuli-Lito, G., Korosevhi, E., Bylykbashi, I., \& Nurce, A. (2018). The Impact of PPROM on Neonatal and Maternal Outcome. International Journal of Ecosystems and Ecology Science2, 8(4), 819-824.

Perry, S., Hockenberry, M., Lowdermilk, D., \& Wilson, D. (2010). Maternal Child Nursing Care (4th ed.). St. Louis: Mosby: Elsevier. 
Sabi'ah Khairi, dkk: Faktor resiko yang mempengaruhi terjadinya ketuban pecah dini di ruang bersalin RSUD Provinsi NTB: Survey Study

Pusat Data dan Informasi Kementerian Kesehatan RI. (2014). Situasi Kesehatan Ibu. InfoDATIN. Jakarta.

Rahayu, B., \& Sari, A. N. (2017). Studi Deskriptif Penyebab Kejadian Ketuban Pecah Dini (KPD) pada Ibu Bersalin. Jurnal Ners Dan Kebidanan Indonesia, 5(2), 134.

Wulandari, E. (2016). Analisis Faktor Risiko Terhadap Kejadian Ketuban Pecah Dini Pada Ibu Melahirkan di RSUD Tugurejo Semarang. Universitas Muhammadiyah Semarang. 